\title{
Newcomers to farming: towards a new rurality in Europe
}

\author{
Neus Monllor i Rico \\ Arrels a Taula \\ neus@arrelsataula.cat
}

Antony M. Fuller

University of Guelph

tfuller@uoguelph.ca

Reception: January 2016

Acceptance: May 2016

\begin{abstract}
One of the oldest laments in agrarian development has been over the ageing and loss of the farm population but, for the first time since the Second World War, a noticeable return to farming is now taking place across most of Europe. These farm entrants we classify as Continuers and Newcomers. Research shows that they have different characteristics. Newcomers are characterized by their profiles (female and higher education), the barriers they face (access to land, capital and markets) and by the business models that they adopt (pluriactive and multifunctional). This paper describes the main features of Newcomers as they form a new and dynamic group in European rural society and contribute strong social motivations and practices to farming. This change may be referred to as a shift from an agroindustrial to an agrosocial paradigm and, together with new social and environmental relations in food systems, forms a new rurality in Europe.
\end{abstract}

Keywords: agrosocial paradigm; farm entry; local food system; newcomers; new rurality

\section{Resum. La pagesia nouvinguda: cap a una nova ruralitat a Europa}

Una de les preocupacions més antigues del desenvolupament agrari ha estat l'envelliment i la pèrdua de la població agrària, però, per primera vegada des de la Segona Guerra Mundial, hi ha un retorn apreciable de la pagesia a bona part d'Europa. Les noves instal-lacions agràries han estat classificades com a pagesia tradicional i pagesia nouvinguda. La investigació mostra que tenen característiques diferents. La pagesia nouvinguda es caracteritza pels seus perfils (femení i educació superior), les barreres que enfronten (accés a la terra, al capital i al mercat) i els models de negoci que adopten (pluriactius i multifuncionals). Aquest article descriu les principals característiques de la pagesia nouvinguda, ja que forma un grup nou i dinàmic dins de la societat rural europea i contribueix amb fortes motivacions i pràctiques socials a la nova agricultura. Aquest canvi es pot entendre com un canvi d'un model agroindustrial a un nou paradigma agrosocial, que, conjuntament amb els moviments socials i ambientals dels nous sistemes alimentaris, formen una nova ruralitat a Europa.

Paraules clau: paradigma agrosocial; instal-lació agrària; sistema alimentari local; pagesia nouvinguda; nova ruralitat 
Resumen. Los agricultores nuevos: hacia una nueva ruralidad en Europa

Uno de los lamentos más antiguos del desarrollo agrario ha sido el envejecimiento y la pérdida de la población agrícola, pero, por primera vez desde la Segunda Guerra Mundial, hay un retorno apreciable a la agricultura en la mayor parte de Europa. Las nuevas instalaciones agrícolas han sido clasificadas como agricultores tradicionales y agricultores nuevos. Nuestra investigación muestra que tienen características diferentes. Los agricultores nuevos se caracterizan por sus perfiles (femeninos y educación superior), las barreras que enfrentan (acceso a la tierra, al capital y al mercado) y por los modelos de negocio que adoptan (pluriactivos y multifuncionales). Este artículo describe las principales características de los agricultores nuevos, ya que forman un nuevo y dinámico grupo de la sociedad rural europea y contribuyen con sus fuertes motivaciones y prácticas sociales a una nueva agricultura. Este cambio puede ser referido como un cambio de un modelo agroindustrial a un nuevo paradigma agrosocial, que, junto con los movimientos sociales y ambientales de los nuevos sistemas alimentarios, forman una nueva ruralidad en Europa.

Palabras clave: paradigma agrosocial; instalación agraria; sistema alimentario local; agricultores nuevos; nueva ruralidad

\section{Résumé. Les nouveaux entrants en agriculture: vers une nouvelle ruralité en Europe}

Un des plus anciens freins au développement rural est le vieillissement et la perte de la population agricole, mais, pour la première fois depuis la Seconde Guerre mondiale, il existe un retour notable à l'agriculture dans la plupart des pays européens. Ces entrants agricoles ont été classés en continuateurs ou nouveaux venus. La recherche montre qu'ils ont des caractéristiques différentes. Les nouveaux venus sont caractérisés par leur profil (femmes et avec des études supérieures), par les obstacles qu'ils rencontrent (accès à la terre, au capital et au marché) et par modèles d'entreprise qu'ils construisent (pluriactifs et multifonctionnels). Ce document décrit les principales caractéristiques des nouveaux venus, qui forment un nouveau groupe dynamique dans la société rurale européenne et contribuent à l'agriculture via leur forte motivation et leurs pratiques sociales. Ce changement peut être considéré comme le passage d'un paradigme agro-industriel à un paradigme agro-social et, de concert avec les mouvements sociaux et environnementaux dans les systèmes alimentaires, il forme une nouvelle ruralité en Europe.

Mots-clés: paradigme agro-social; installation agricole; système alimentaire local; nouveaux entrants; nouvelle ruralité

\section{Summary}

1. Introduction 4. The Agrosocial Paradigm:

2. Who are the Newcomers?

3. Do Newcomers constitute a New Rurality? a new framework for Rural Development in Europe

5. Conclusions

Bibliographical references 


\section{Introduction}

Newcomers to farming in rural Europe are the focus of this paper. We contend that they are bringing about a series of changes that can be described as a new rurality: something that is new and which encompasses different rural areas and farming styles. In contrast to the diminishing flow of Continuers to existing farms, there appears to be a growing number and variety of Newcomers to farming. Whether this wave of Newcomers is a response to the predations of the industrial food system or the growing public demand for safe local food, among other motivations, has yet to be demonstrated, but it certainly underpins the purpose of this research.

Newcomers include those who do not, in general, have a connection to an existing farm and who find a way into farming by various routes, many of them unorthodox, to start new and often innovative enterprises. They bring new ideas, methods and means to the local farming and livelihood nexus. Who are these Newcomers and what are they contributing to agriculture and rural development in terms of innovation and sustainability? More specifically, are their efforts having an impact ecologically, socially or economically on household livelihoods, community well-being and regional development? Do they represent a new force of change in rural Europe?

Change is constant in almost all rural environments. What differs is the direction, volume and impact of change and whether such change is stimulated from within or from without the existing over-capitalised food system. Most rural change is evolutionary and incremental and therefore quasi-predictable; other changes, less frequent, are surprising and unexpected. What becomes important, therefore, is whether the change has enough force to be registered as a 'new normal', with the recognition that it will never be quite the same again. In this sense, accounting for change is reflexive and subjective; it depends on who the observer is. The elderly have seen many a 'new normal'; teenagers only know the present as normal. Change therefore is about what we witness and what we register cognitively and collectively as different. In this paper, we use the word 'new' carefully as this implies a potential change. What exactly has changed, how and why, and what are the implications are the critical followup questions.

Change in the form of a reverse process is one brought about after many years of a well-documented trend or problem. The growing number of Newcomers to farming is one such reversal, as it comes after fifty years of observing, statistically and otherwise, the steady decline and ageing of the farm population. In many parts of rural Europe, there are observable trends of Newcomers to agriculture and, although only in modest numbers for the most part, there are clear signs of significant renewal of the farm population in some areas. Based on this general observation, we will argue that this change is affecting not only farming and the food system, but that it is embedded in other dimensions of change that contribute to what we can call a new rurality: a new normal in rural life. As with most forms of social change, the early incidence 
and distribution of the phenomenon is uneven and unpredictable. It seems that we are at that stage with Newcomers to farming in Europe.

The object of this paper is twofold. It is first necessary to establish if there are indeed Newcomers to farming, what their profiles are and in what ways they differ from Continuers in the entry process. The second objective is to examine whether the Newcomers and their general characteristics contribute a new form of 'energy' in rural areas which can be described as a new rurality.

To examine this proposition and to verify whether there is sufficient evidence to assert that the Newcomers to farming are a passing phase or a component of the new rurality, first we review an international comparative study by one of the authors and then the situation in rural Europe using both the literature and the recent work of the European Focus Group project "New entrants to farming: lessons to foster innovation and entrepreneurship"1.

\section{Who are the Newcomers?}

\subsection{Newcomer: Definitions}

One of the early efforts in Europe to identify different categories for farm entry was made by Monllor (2011). In order to establish the characteristics of farm renewal in two study areas, she formulated a hypothetical proposition whereby entry to farming was conceptually assumed to be either: 1) Continuers, those who take over the family farm or 2) Newcomers, those who enter farming without any previous connection to agriculture. This dichotomy was established in order to know if or in what ways the two main groups were different, based on their entry path, and general characteristics.

The research approach was based on a comparative exploration using mixed methods, being a combination of qualitative and quantitative techniques. The comparative dimension was between two different rural areas: Southwestern Ontario (Canada) and the province of Girona in Catalonia (Spain). The areas of study in Ontario and Catalonia were chosen because both have the same problem of an ageing farm population, but different policy approaches to the same farm entry issue.

For sampling and data collection, the snowball technique proved to be a good way to identify farm entrants in the two areas of study. Data were collected with a questionnaire survey administered by personal interview. At the end, the sample was configured with 50 farm people in each study area. This number corresponds to the criterion of theory saturation (Taylor and Bogdan, 1992: 90; Baylina, 2006: 126). The field work was conducted in two phases: between June and August 2008 in Southwestern Ontario and between March and September 2009 in the Girona area.

1. The Focus Group "New entrants to farming: lessons to foster innovation and entrepreneurship", was established under the European Innovation Partnership Agricultural Productivity and Sustainability (EIP-AGRI). It brought together 19 experts from across Europe, which met once in June and once in November of 2015. The results can be seen at the EIP-AGRI website (<http://ec.europa.eu/eip/agriculture>). 
The result analysis phase involved both quantitative and qualitative analysis in order to provide a comprehensive understanding of the complex reality of entry into farming. Regarding the data analysis, for quantitative data, once the field work was done, a data matrix using an SPSS program to process the information was developed. The closed questions were identified directly by a code, but the open ones required a careful process of closing them for coding. For the qualitative analysis of the personal views and indicators of attitudes within the questionnaire, a transcription of relevant paragraphs was selected in order to clarify and enrich the quantitative data results. Choosing the most relevant and appropriate quotes to provide additional evidence and to illustrate the dynamic practices and thoughts of the farmers in the sample was a concluding exercise. The combination of the two techniques was very useful as it enabled evidence from the two areas to be compared and to support the discussion of the results.

Following the early definitional work of Monllor (2011), a more complex formulation was put forward by a European Focus Group in "New entrants to farming: lessons to foster innovation and entrepreneurship." The Focus Group operated as a think tank to discuss most of the issues affecting the entry process related to newcomers into farming in Europe.

The European Focus Group definition states that a New Entrant ${ }^{2}$ into farming is "a natural person or group of people who have, within the past ten years, established a new agricultural holding, farming business or cooperative. The natural person or group of people should be actively farming and be either establishing a new agricultural holding or returning to a family-held holding after a minimum of ten years of off-farm education or employment." The definition excludes agricultural workers and direct successors who have worked on a farm for most of their adult life. The most important question defining Newcomers for the Focus Group is whether the person who is entering the sector has had family ties to farming since he or she was a child. If there are many farm entrants with no links to farming this clearly indicates that something significant is changing in farm renewal.

The work of the European Focus Group established eleven different profiles of farm entrants (Figure 1). With the question of "Were you raised on a farm?" a whole set of path options is taken into account in order to assess the best descriptor of a farm entrant. It provides six different categories for Newcomers (diversified, innovative, full-time, part-time, hybrid and hobby farmer) and five different categories for Continuers (diversified, innovative, direct, indirect and delayed).

Following the question of whether the person has been raised in a farm, other aspects are taken into account in order to define the profile of the farm entrant. Different characteristics such as off-farm work, major changes in the farm, diversification or access to land have been included as pathway descriptors. The eleven categories show the richness of current renewal in

2. Note that the European Focus Group uses the term "New entrant" to refer to the same concept as "Newcomer". In this paper, we will only use the term Newcomer. 


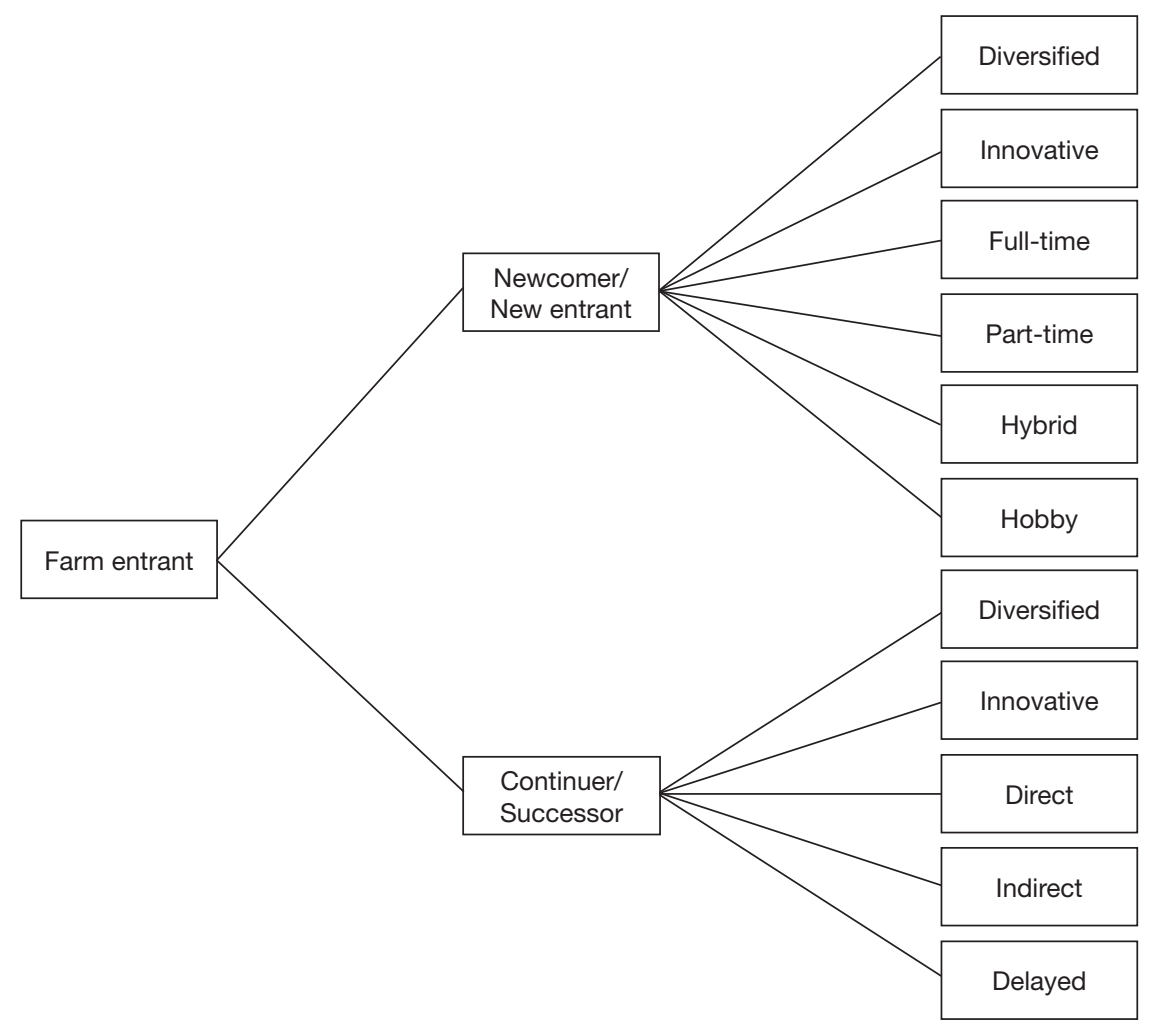

Figure 1. Entrant Options.

Source: prepared by the author based on the Final Report of the European Focus Group "New entrants into farming".

agriculture, clearly more than a simple pathway of continuing the familiar activity on the farm.

Finally, we should take into account that the concept of Newcomers is not restricted to young farmers. In the Eurostat definition, a young farmer is a farm holder between 18-35 years old. On the other hand, for Council Regulation (EC) No. 1698/2005, a young farmer is a person "under 40 years of age, possessing adequate occupational skills, setting up on an agricultural holding for the first time" (EC, 2005). The Newcomer definition included people of all ages.

\subsection{Newcomer: profiles}

The Monllor data shows that the two study groups, Continuers and Newcomers, are different (Table 1). They follow different pathways to enter farming 
Table 1. Continuers and Newcomer profiles

\begin{tabular}{lcc}
\hline & Continuers & Newcomers \\
\hline Male & $85 \%$ & $47 \%$ \\
Female & $15 \%$ & $53 \%$ \\
Age at start-up & 21,9 & 26,5 \\
Rural background & $100 \%$ & $43 \%$ \\
Urban background & $0 \%$ & $57 \%$ \\
Secondary school education & $63 \%$ & $13 \%$ \\
University education & $16 \%$ & $60 \%$ \\
Website of the business & $9 \%$ & $60 \%$ \\
Business plan & $15 \%$ & $55 \%$ \\
\hline
\end{tabular}

Source: Monllor (2011).

and have gender and education characteristics that also have different patterns. These results show two different profiles. The Continuer is a man who has set up on the family farm after finishing Agriculture College in his early twenties. He does not have his own website nor a business plan. The Newcomer is more likely to be a woman who has set up in farming after finishing her university studies (not related to agriculture) and enters farming in her late twenties. She has her own website and uses a business plan to develop the farm operation.

In the Monllor sample, the gender issue was significant: farmers who grew up on a traditional farm were mostly men, just $15 \%$ being women, while in the Newcomer group there were more women entrants (53\%) than men. Recent studies have shown that, on average, women are more likely to be involved in small-scale, diversified and organic farms, compared with men (Binimelis et al, 2008; Ahearn and Newton, 2009; Pinto-Correia et al, 2013; Wilbur, 2013 and Seuneke and Bock, 2015).

The type of education is also different depending on whether they are Continuers or Newcomers. It was found that farmers coming from farm family backgrounds finish agricultural college studies (63\%), while Newcomers are more likely to have finished university studies (63\%), most of them in such disciplines as environmental science, social science or policy studies. Madureira et al. (2015) also found that there is a predominantly higher educational level among Newcomers than the average amongst Continuers.

The European Focus Group analysis also emphasised the specific skills and expertise that Newcomers bring to farming from outside the sector. Some examples are related to communications, innovative business development, or new technology. Monllor's sample also brings evidence related to the use of websites on the part of Newcomers, mostly to make them visible and sell their products directly to the consumer.

Finally, it is interesting to take into account some of the motivations of Newcomers. The European Focus Group identified lifestyle aspirations, work ambitions, market opportunities, urban stress, and health aspirations as the five primary drivers to become a farmer from scratch. There are also other motiva- 
tions such as reconnecting people with the origin of food or being part of a sustainable movement to develop eco-friendly food systems at the local level.

\subsection{Newcomers: main barriers}

Newcomers face many difficulties in gaining a foothold in farming. The European Focus Group identified three major barriers to entering the sector: 1) access to land, 2) access to capital and 3) access to markets.

Access to land is identified in most studies as the primary barrier to entering agriculture (Williams, 2006; Ingram and Kirwan, 2011; Miler and Butler, 2014). First of all, the Newcomer has to know where to look in order to find farmland that is available. After that, there are problems in buying good land because of high prices and there are also problems in renting land because of the mistrust of owners who most often prefer to rent to an established farmer (Ilbery et al., 2010).

Access to capital and high startup costs are also identified as strong barriers for Newcomers. Once land is available, other assets like machinery, buildings, and livestock may be required. Beginning a farm from scratch has long been considered virtually impossible. This is one of the reasons why most Newcomers enter agriculture in small-scale enterprises, mostly in horticulture. The way they access capital differs from the general farmer, with high interest rates, stringent requirements for securing loans, and a lack of trust from commercial banks making it hard to access funds to begin a farm.

Access to markets is another key difficulty. Although most Newcomers are finding outlets at the local level, scaling-up prospects remain limited. Short food supply chains are actively being developed in Europe as a pragmatic way to help Newcomers sell their products at the local level, but it seems not to be enough for all Newcomers to make a living.

Some of these barriers can vary geographically. Rural Europe is diverse and multiple scenarios can be found in the same geographical area. For example, issues related to legal structures, policies and programs for Newcomers, or geographic conditions that could help or hinder a newcomer in getting established have to be taken into account.

\subsection{The Newcomer Pathway to Farming}

One way to systematize the main barriers that Newcomers face is to identify the "pathway to becoming a farmer." Despite the diversity of the various personal stories of farm entrants, Newcomers and Continuers share common phases in the entry process. The following figure based on the Monllor (2011) data shows the main stages of entry, disaggregated into two different periods of time: the planning period (before entry) and the establishment period (after entry).

The planning period contains, firstly, the exploration phase. Here the Newcomer is following the motivations that make him or her want to become a farmer and the possibilities of achieving them. The decision phase implies 


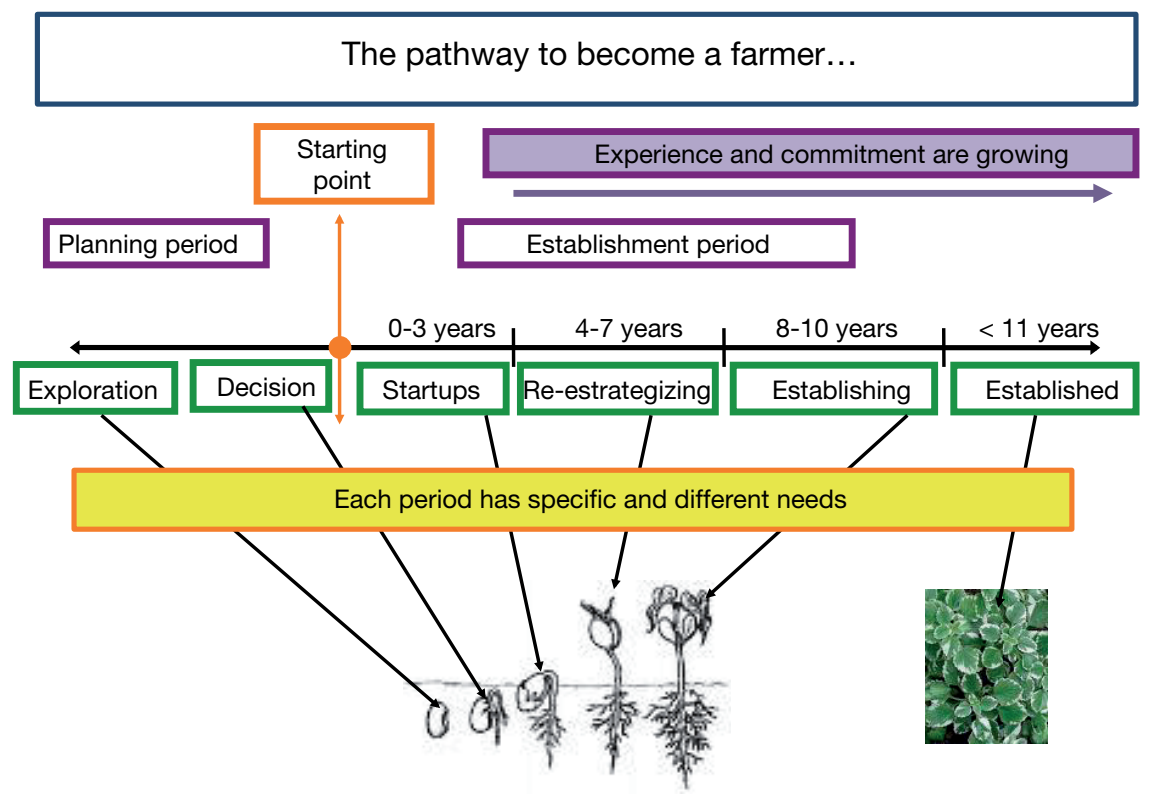

Figure 2. The pathway to become a farmer.

Source: Monllor (2011).

a more committed position from the Newcomers. There are decisions about which sector to start up in, in which location, and for what market. After this phase, the Newcomer is already at the starting point.

The establishment period has four different phases. The first one is the startup phase and occurs just after the starting point, the moment when the Newcomer begins to make decisions in farming. This is the most vulnerable phase in the pathway because of the common lack of experience, market knowledge, and confidence. The re-strategizing phase, is where the Newcomer knows more about what to expect and can re-consider how to achieve the main goals. In some cases there is a reorganization of strategies on the farm. After more or less eight years there is the establishment phase, the moment when the farmer is settled and well positioned in the field. Some changes can be made, but usually not strategic ones. Finally there is the established phase, considered the last step of the entry process. Understanding farm entry as a process is a crucial step to fostering a new generation of farmers in Europe and is of direct relevance to policy.

Newcomers have different necessities, constraints, skills, and assets when setting up in farming than Continuers. Mainly for this reason we should carefully consider the main characteristics of the Newcomers in order to understand who they are, what they are doing, and what they want to do in the future. 


\subsection{Newcomers: Business Models}

Most of the literature (Madureira et al, 2015; Sutherland et al. 2015; Wilbur, 2014; Zagata and Lostak, 2014) confirms the high level of innovation that Newcomers are bringing to agriculture. The profile of a Newcomer business model is based on diversified small-scale farms, selling directly to consumers and working in an eco-friendly way. These characteristics show that Newcomers are producing food in a manner that differs from the conventional farming food chain, where intensification, specialization, equalising distance and enlargement are the common trends.

The Monllor (2011) comparative research shows that most of the Continuers $(85 \%)$ start on the family farm, keeping on with the same production enterprise, which mostly reflects the dominant form of agriculture in the area, such as milk production or cattle raising. The major tendency is to get bigger to take advantage of economies of scale, to invest in machinery to reduce labour costs and to sell their product to an intermediary or food company (73\%). Most Continuers have the farm operation already running, with attendant obligations and debts, so it is very difficult, at first, to change to another farming model. Most Continuers are partners with their family members. This represents a strong form of path dependency.

On the other hand, Newcomers begin new farms, predominantly enterprises that are growing vegetables (56\%) and raising sheep (19\%) and they overwhelmingly tend towards organic production (81\%). They mainly tend to operate on a small scale, not to make big investments in the early stages and to sell directly to the consumer (88\%). Many Newcomers, for example, are engaged at one time or another with Community Supported Agriculture models which engage urban consumers either directly at the farm or through various food basket delivery programs.

Another interesting pattern that is repeated all over Europe is that Newcomers are more likely to be engaged in horticulture, as it is the sector that requires less farmland for profitable revenues, and lends itself to direct marketing and local food systems. A considerable number of Newcomer farms are small-scale and labour-intensive and require low capital investments (Monllor, 2011; Wilbur, 2014), and horticulture is one way to mobilise these assets, even if it means great stress in peak labour periods.

Another common characteristic is that most Newcomers use eco-friendly production styles: organic, biodynamic or ecological farming systems. There is increasing evidence that a large number of organic farmers tend to be newcomers (Rigby et al., 2001; Padel, 2001; Lobley et al., 2009; Binimelis et al, 2008).

Practices around Europe show how Newcomers are creating innovative businesses that are different from the mainstream agricultural sector. Sutherland et al (2015) found that Newcomers closer to urban centres were creating value-added farming activities such as alternative agri-food networks or local certification schemes. Brunori et al. (2011) demonstrate that Newcomers are 
more likely to establish virtual communities using information communication technology tools such as on-line networks.

Finally, it is worth taking into account the differences related to geographic location. For example, peri-urban areas are more likely than industrial and conventional farming areas to involve Newcomers, mostly on diversified farms selling directly to consumers in the cities (Pinto-Correia et al, 2015). However, it is also quite common for Newcomers to find land for farms in remote areas where the price of the land is more affordable. The Pinto-Correia et al. research found that the Newcomers are contributing to improvement of the environment by occupying abandoned land, by recovering traditional practices, and also by promoting social benefits in rural areas.

The data emphasizes how different the farm enterprises are in relation to the family background of the farm entrant. Continuers are mostly following the tradition of their parents who have opened this pathway to them, the pathway of getting bigger and more capitalized. Newcomers begin a new pathway by setting up a small and diversified farm, with low investments that are easier to manage in the early stages.

\section{Do Newcomers constitute a New Rurality?}

To explore whether the Farm Entrants, both Continuers and Newcomers, collectively provide a new 'energy', a new way of doing and thinking, in rural areas that could be described as a New Rurality, we need to deepen our analysis of who the new generation of farmers are and how their practices and attitudes affect rural systems. To accomplish this we return to the comparative study undertaken by Monllor (2011).

Theoretically, we can generalise about the established commercial farms in Southern Ontario and Girona as being driven by the singular rationality of the economic imperative.. The earlier family farm roles such as community building and landscape preservation have gradually fallen away as the pressures of economic survival have increased and the optics of "bigger is better" has prevailed. Farmers have been renamed 'producers' and many have lost touch with the institutions and services that their forbears established in the local community. It is our assertion that this de-linking runs counter to the approach of Newcomers to farming.

With the objective of establishing what ethics and abilities are driving today's farmers, a deeper analysis of farm practices in agriculture and farmers' attitudes towards the future of rural areas was undertaken. To understand better the relationship between Farm Entrants and a changing paradigm it was necessary to measure practices in agriculture on the one hand and attitudes to new concepts and ideas in farming, such as environmental sustainability, social responsibility, rural community and food safety, on the other. In order to create an analytical framework it was necessary to define specific components of a new scenario that would measure differences between Continuers and Newcomers. 


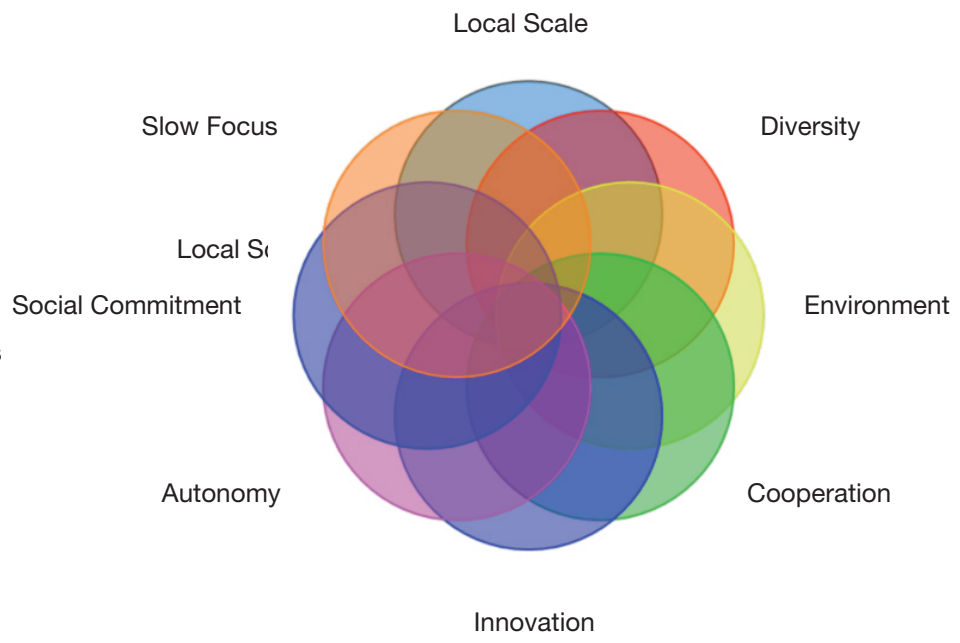

Figure 3. Components of the Agrosocial Paradigm.

Source: Monllor (2011).

After a review of the literature on rural futures, the formulation by the Organization for Economic Co-operation and Development of the New Rural Paradigm (OECD, 2006) was chosen to determine five of the main components (Local Scale, Diversity, Environment, Cooperation and Innovation) of the framework. Complementary literature, consisting mostly of Van der Ploeg's New Peasantry ideas (2008), was used to strengthen the theoretical rationale of the framework. Three more components were added to the first OECD set (Autonomy, Social Commitment and Slow Focus), all of which are shown in Figure 3.

The selection of the eight components was a way to create a theoretical framework with which to measure the significance of a new reality related to farm entry. Monllor named it the Agrosocial Paradigm. The early hypothesis that Continuers and Newcomers were different was put to the test in a systematic way. This formulation of eight measurements, created by the methodology to compare the two groups in the study, is named the Agrosocial Paradigm Index. The index measures on a systematic scale how far farm entrants are from the attributes of the Agrosocial Paradigm.

The index was built in two different parts, one for agricultural practices and the other for attitudes towards a farming future. The part related to the practices measures what farmers are consciously doing in their daily work on the farm in relation to their socio-economic and physical environment. The part related to attitudes measures the approximate place the farmer is between the old (agroindustrial) paradigm and a new (agrosocial) paradigm, in relation to the ideas and thoughts he or she has for the immediate future. The data analysis results (Table 2, Figure 4 and Figure 5) compare Continuers with 
Table 2. Index scores for Continuers and Newcomers related to practices and attitudes

\begin{tabular}{lcc}
\hline Index & Continuers & Newcomers \\
\hline Practices & 3.9 & 7.0 \\
Attitudes & 6.0 & 7.6 \\
Agrosocial Paradigm Index & 4.9 & 7.3 \\
\hline
\end{tabular}

Source: Monllor (2011).

Newcomers, based on a scale of 0 to 10 . The maximum score obtainable is 10 , which indicates that practices and attitudes are very close to the agrosocial paradigm.

The results show that Continuers are far from the Agrosocial Paradigm in practice, and that traditional roles continue to define the daily routine on most conventional farms. Most of them follow the logic of intensification and specialization, competing in a global food system and implementing scale strategies to make their farms profitable.

Practices are reflective of the reality of farming in the daily life of the entrant farmer. Figure 4 shows the differences between Continuers and

\section{Local Scale}

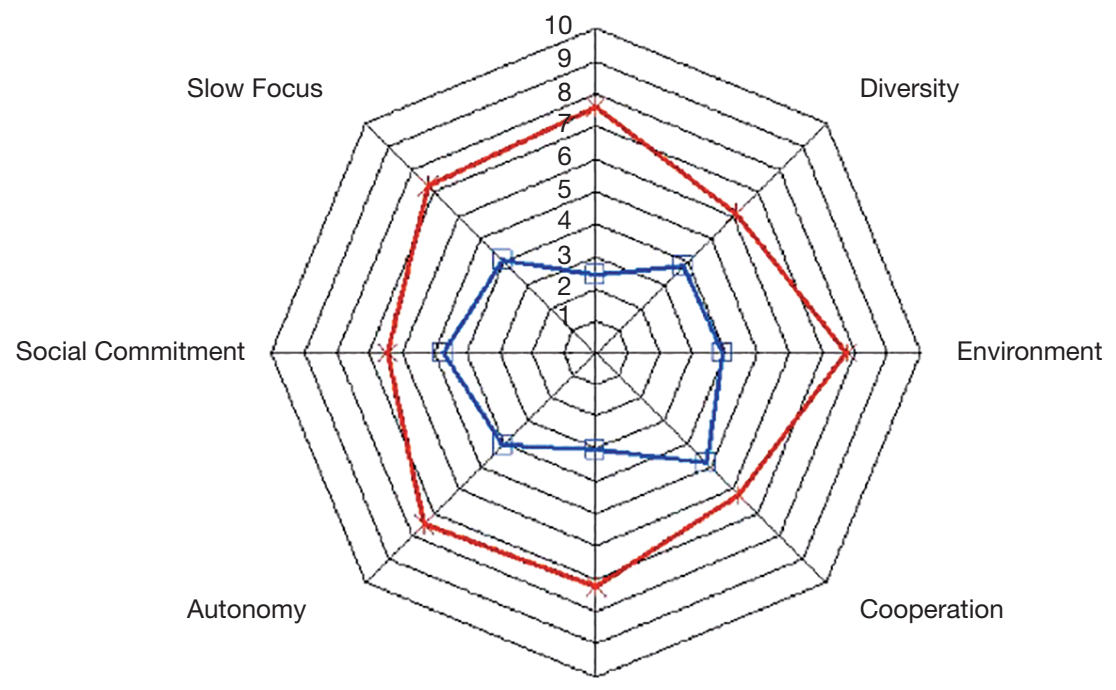

Innovation

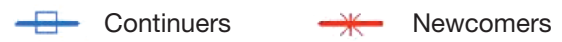

Figure 4. Index Scores for Continuers and Newcomers Related to Farm Practices.

Source: Monllor (2011). 


\section{Local Scale}

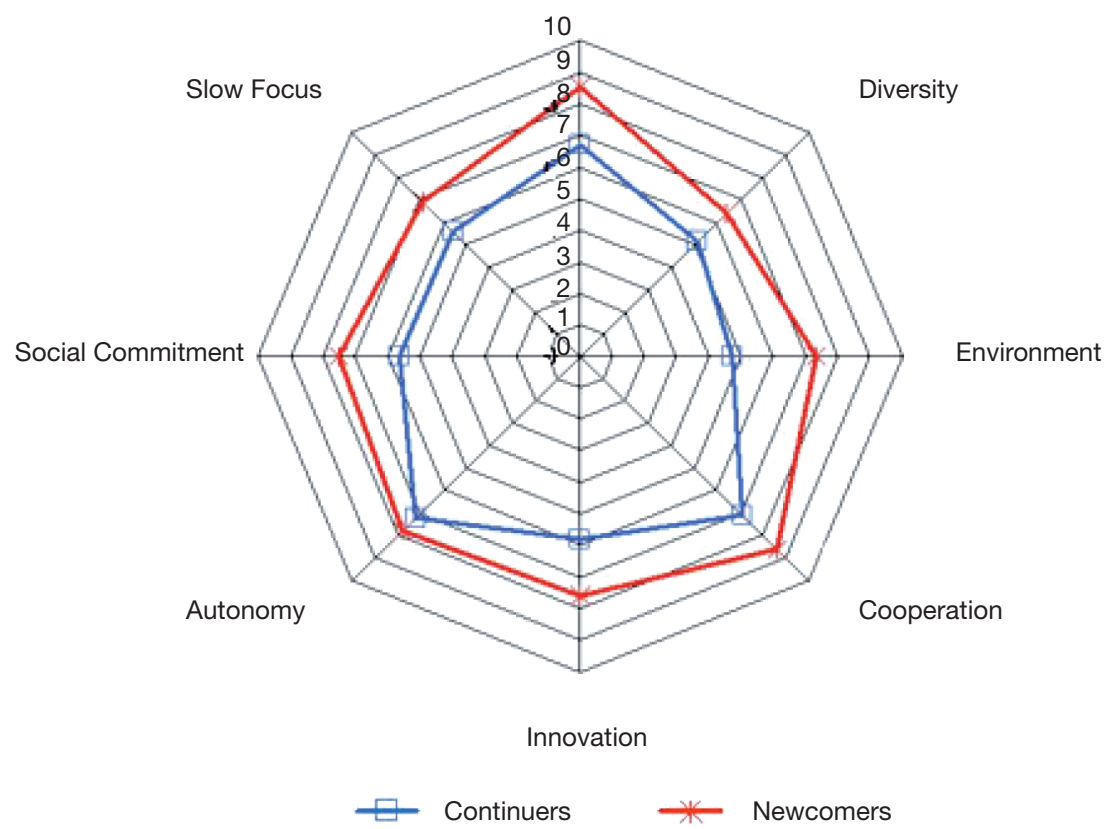

Figure 5. Index Scores for Continuers and Newcomers Related to Attitudes.

Source: Monllor (2011).

Newcomers for each of the eight components of the Agrosocial Paradigm. The components that display the greatest differentiation are Local Scale, Innovation and Environment. This means that the way farm entrants act is rooted in two different agriculture models of farming. On the one hand, Continuers are far away from the local scale (for example selling directly to the consumer), they are not likely to implement alternative innovations other than technological ones and they are less likely to follow environmentally friendly practices. On the other hand, Newcomers have adopted these three components as a strategy to enter agriculture. They value the proximity of agriculture to the consumer, they introduce new innovative practices in many spheres in their enterprises and they grow organic food and take great care of the natural resources close to the farm.

Regarding attitudes, we refer to the way farmers think about the future in agriculture as a worldview, which is one way to reflect their reality. The reason for measuring farmers' attitudes to an Agrosocial Paradigm is to get a better idea of how they see the future direction of rural life. Figure 5 shows how both Continuers and Newcomers are open, in different degrees, to new ideas. That means the way farmers are thinking about the future of farming, gene- 
rally speaking, includes many of the components of the Agrosocial Paradigm. For example it is clear that some farmers will have to reorient their strategies towards growing food for a local market, however defined, measured by the Local Scale component. It is also important to note the desire of farmers to be more autonomous vis à vis the banks, the big corporations, chemical and seed supply companies and expensive machinery, etc. We can observe this tendency through the Autonomy component and what the respondents commented on. The score on the Cooperation component indicates that farmers are showing their support for cooperation even if for most of them it is difficult to achieve. It is important to note that a handful of both Continuers and Newcomers are fully orientated to this new way of thinking in agriculture.

Thus, one of the important results is that Continuers are closer in attitude to a paradigm change than expected. The analysis makes evident that the practices of Continuers following the family pathways are still rooted in the old productivist paradigm, but there is a different result when we pay attention to attitudes and discover that Continuers have a more agrosocial outlook than their practices show. This result raises an interesting question about what farm entrants appear to be compelled to do in farming compared to what they might like to do. Continuers, many with binding contracts and heavy debt loads, tend to maintain the previous family trajectory and, therefore, are obliged to keep up the old productivist paradigm, but some of them visualize possible changes for future strategies related to local food systems or to environmentally friendly practices. Importantly, it has to be noted that Continuers are rarely able to change their operations once they take over the farm, even though they may have alternative and eco-friendly ideas. This is attributed to a form of path dependency whereby the scale of operation and the debts incurred in the transfer determine that continuers do indeed continue the same farm practices as the previous operators.

On the other hand, it was found that Newcomers are consistently closer to the Agrosocial Paradigm, both in their practices and attitudes. Most of the practices are related to a new way of farming, taking into account farm diversification, direct marketing, cooperation with consumers, ecological practices, etc. Newcomers bring new ideas and innovation as a way to compete and make a living from the farm. Multifunctional strategies are implemented by most Newcomers to farming, providing different options and opportunities to try new things and to achieve personal objectives that may have both material and spiritual dimensions. In sum, Newcomers with agrosocial beliefs have more space and freedom to operate and innovate than Continuers.

\section{The Agrosocial Paradigm: a new framework for Rural Development in Europe}

The Agrosocial Paradigm is a way to describe a new rural development perspective in Europe. Evidence from practices shows how actors are reconstructing a new way to live in the territory (Ploeg et al, 2015). Not all agricultural 
practices promote the same model of development. The activities undertaken by Newcomers to farming in an agrosocial context create strong social capital, further the connections between rural and urban spheres, aim for optimal food quality and better health, re-inhabit abandoned areas, create new social relations, propose alternative ways of organizing and collaborating, bear in mind future generations, and strive to maintain a rich, diverse and economically dynamic agricultural area. All these attributes together make up rural development, a concept that has been studied and revised considerably in past and present literature (Etxezarreta, 1987, European Commission, 1988; Hervieu, 1997, Bryden, 2000; Ploeg et al. 2000; Viladomiu, 2003; Monllor et al,. 2005; OECD, 2006, O'Connor et al., 2006; Ploeg and Marsden, 2008 and Milone et al., 2015).

Based on the evidence presented here, Newcomers to farming are reconstructing the profile of farm renewal in Europe. The agrosocial models they are implementing as pioneers are being followed by some Continuers who also believe that another, less invasive, way of farming is possible. Alternative food systems are showing positive externalities in terms of social and environmental issues. Qualitative evidence from Monllor's work and stories reported from around Europe $^{3}$ demonstrate that a new generation of farmers constructing an agrosocial paradigm are locality-rooted, foster farm diversification, promote environmentally friendly practices, cooperate to advance their common cause, introduce appropriate technologies, explore their own autonomy and fight for future generations, and many are trying to reduce the capital intensification of conventional farming practices. They are fighting for sustainability in most senses of the word.

Given that the profile of farm entrants is heterogeneous and that Newcomers are bringing innovative ideas into local operation, it follows that there is a need to recognize the key role this new wave of farmers has. They are the pioneers upon which a whole plethora of activities are based, from new networks and associations (chefs, restaurants, farmers, schools, etc.) to new linkages among them. New businesses abound in the delivery, and support services fields (design, packaging and marketing). Thus, in the past ten years several reports, books and articles have appeared that provide numerous examples of such activities creating new spaces to act in different ways (Maynard and Green, 2006; Aurélie, 2007; Mailfert, 2007; Binimelis et al. 2008; Ploeg, 2008; Gillespie and Johnson, 2010; Euskadiko Gazteriaren Kontseilua, 2010; Niewolny and Lillard, 2010; Elton, 2010; Perez-Vitoria, 2010). This does not mean that only Newcomers are implementing agrosocial practices but that most Newcomers bring innovation to agriculture while just some of Continuers are implementing new strategies to improve the agrosocial qualities of their life and styles of farming (Monllor, 2011).

The new agrosocial enterprises are building up new socio-political relations in rural areas, and also between rural and urban areas. A new wave of bold

3. See "Case study posters" in <https://ec.europa.eu/eip/agriculture/en/content/new-entrantsfarming-lessons-foster-innovation-and-entrepreneurship>. 
initiatives and projects is sweeping across Europe to create a system whereby an increasing number of farmers are once again close to consumers and the demand for local, healthy, organic and fresh food is growing. There appears to be a new generation of farmers with diverse backgrounds and experiences who are ready to feed this new trend. It is also important to take into account the need to build bridges between Continuers and Newcomers, old and young, rural and urban, producers and consumers, to form new networks and hubs in an emerging new food system.

New entrants, then, are a part of a general shift in values and behaviours within the farm sector in Europe, but are only part of the changes being witnessed. The Agrosocial Paradigm also encompasses other changes in the food movement, including consumer behaviour and increasing environmental awareness, all of which supports the initiatives of Newcomers and their farm and lifestyle enterprises. Newcomers are part of a wider movement to rebalance the food system, create more close-knit communities, and enhance the environment, especially in an era of climate-change awareness. They strive to create more space and freedom to find their place among these multiple options and goals in such a way that new interpretations of association and community, as well as innovative activities are emerging. The fact that this is a universal phenomenon is demonstrated by Milone, Ventura and Ye (2015) in reporting on activities in North-Western Europe, South America, and China.

Finally, Newcomers are already recognised as valuable members of rural society and this requires support and assistance for them to remain viable and innovative in their role as providers of new forms of food production. Although many eschew government intervention, useful development aid could be supplied in the form of education and training, for example in organic techniques and animal welfare, new cooperatives and creative farmer associations. A new generation of facilitators is required to help link farmers with cooks, schools with fresh food supplies, and the tourism sector with local specialties. All such socially creative activity can consolidate the sector in which Newcomers are embedded so that they become the new normal in rural areas.

\section{Conclusions}

There is a new dynamic in rural Europe which is rooted in the resurgence of a new generation of farmers, mostly Newcomers, but including some Continuers, who form the basis of a New Rurality. From multiple sources it has been shown that the majority of Newcomers to farming have strong connections to social values in their lifestyles and are motivated by different ethics to those of conventional productivist farmers. Such Newcomers are becoming progressively recognized in the form of institutional support for their presence and activities in the agricultural sector. They are considered an essential part of the new food movement which is being driven by consumers seeking safe food and healthy lifestyles, in addition to environmental enhancement. Such is the volume (small, but significant) and nature (social and alternative) of the 
newcomers' presence that it is becoming a new normal. It is not unusual for a Newcomer to become a modern shepherd, to raise free-range organic chickens, to cultivate flowers or to be involved in value-added activities on their farm, or for women to be farmers. To judge from their attitudes and practices, most Newcomers are following agrosocial principles, inherent in their outlook, and collectively they are forming a new group in rural society that has strong environmental and social ethics.

In the broad picture, a new generation of farmers is a central component of a paradigm shift, here referred to as agrosocial, which is on-going and dynamic. Newcomers are a central part of the new food system, are strongly connected to environmental movements, and form on their own behalf a new social dynamism that involves community, place, and cooperation. As new peasants they form and reform new spaces to try out their ideas and to gain in number. In their connections to other social actors, Newcomers are the pioneers of change and development in local areas and can be considered central components in the new ruralities of Europe.

\section{Bibliographical references}

Barham, Brad; Jackson-Smith, Douglas; Stevenson, Steve and Taylor, Jennifer (2001). Nurturing the Next Generation of Wisconsin's Dairy Farmers. Madison: Center for Integrated Agricultural Systems and Program on Agricultural Technology Studies, University of Wisconsin-Madison.

Alberdi Collantes, Juan Cruz (2002). "El caserío agrícola vasco en proceso de desaparición". Ería, 57, 5-17.

Aurélie, Annette (2007). La Via Campesina. La globalización y el poder del campesinado. Madrid: Editorial Popular.

Berry, Wendell (1981). The gift of good land. San Francisco: North Point Press.

Binimelis, Rosa; Bosch, Mariona and Herrero, Amaranta (2008). A sol i serena. dones, món rural i pagesia. Barcelona: Institut Català de les Dones, Generalitat de Catalunya.

Brunori, Gianluca; Rossi, Adanella and Malandri, Vanessa (2011). "Co-producing transition: innovation processes in farms adhering to solidarity-based purchase groups (GAS) in Tuscany, Italy". International Journal of the Sociology of Agriculture and Food, 18, 28-53.

Bryden, John (2000). "Is there a New Rural Policy in OCDE countries?". International Conference on Rural Communities and Identities in the Global Millennium. Nanaimo, Canada, 1-4 May 2000.

Caldwell, Wayne and Hilts, Stew (2005). "Farmland preservation; innovative approaches in Ontario". Journal of Soil and Water Preservation, 60 (3), 66-69.

Catherine, Milne and Allan, Butler (2014). Young Entrants to Farming: Explaining the Issues. Policy Briefing. Rural Policy Center. March 2014 (RPC PB 2014/02).

Euton, Sarah (2010). Locavore: From Farmers' Fields To Rooftop Gardens - How Canadians Are Changing The Way We Eat. Toronto: HarperCollins.

ETXeZARRETA, Miren (1987). El desenvolupament rural integrat. Barcelona: Diputació de Barcelona, Quaderns Rurals.

European Commission (1988). The future of rural society. Commission communication transmitted to the Council and to the European Parliament. 
Euskadiko Gazteriaren Kontseilua (2010). “Jóvenes Baserritarras. Situación socioeconómica de la juventud agroganadera en la CAPV”. Hizpideak, 4, 1-36.

Gillespie, Gilbert and Johnson, Sue Ellen (2010). "Success in farm start-up in the Northeastern United States". Journal of Agriculture, Food Systems and Community Development, 1, 31-48.

GonzÁLEZ, Juan José (2002). “Juventud rural y relevo generacional en la agricultura”. Políticas de relevo generacional e incorporación de la mujer el mundo rural. Madrid, 2002.

Hervieu, Bertrand (1997). Los campos del futuro. Madrid: Serie Estudios del Ministerio de Agricultura, Pesca y Alimentación.

Ilbery, Brian and Bowler, Ian R. (1998). "From agricultural productivism to postproductivism”. In: ILBERY, B. (ed.). The geography of rural change. London: Longman Ltd., 57-84.

Izcara Palacios, Simón Pedro (2005). "La crisis de sucesión generacional en la agricultura japonesa”. Estudios agrosociales y pesqueros, 207, 51-77.

Lefebvre, François; Quelen, Mickaël and Leseigneur, André (2004). "Le devenir des agriculteurs aidés, installés hors du cadre familial”. Structures Agricoles, 14, 45-48.

Lobley, Matt and PotTer, Clive (2004). "Agricultural change and restructuring: recent evidence from a survey of agricultural households in England". Journal of Rural Studies, 20, 499-510.

Lockwood, Jefferey A. (1999). "Agriculture and biodiversity: finding our place in this world”. Agriculture and Human Values, 16, 365-379.

Lovelock, James (2007). La venganza de la tierra. Barcelona: Planeta.

Madureira, Lívia et al. (2015). "Designing, implementing and maintaining agricultural/rural networks to enhance farmers' ability to innovate in cooperation with other rural actors". [Available at: <http://www.proakis.eu>].

MAILFERT, Kate (2007). "New farmers networks: how beginning farmers build social connections in France". Tijdschrift voor Economische en Sociale Geografie, 98 (1), 21-31.

Marsden, Terry (2003). The condition of rural sustainability. Wageningen: Royal Van Gorcum.

Maynard, R. and Green, M. (2006). Organic works. Providing more jobs through organic farming and local food supply. Bristol: Soil Association.

Medina, F. Xavier (2010). "Introducció: reflexions sobre les alimentacions contemporànies”. In: Medina, F. Xavier. (ed.). Reflexions sobre les alimentacions contemporànies. De les biotecnologies als productes ecològics. Barcelona: Editorial UOC, 11-22.

Milone, Pierluigi; Ventura, Flaminia and Ye, Jingzhong (eds.) (2015). Constructing a new framework for rural development. Research in Rural Sociology and Development (Vol. 22). Bingley: Emerald Group Publishing Limited.

Monllor, Neus (2011). Explorant la jove pagesia: camins, pràctiques $i$ actituds en el marc d'un nou paradigma agrosocial. Estudi comparatiu entre el sud-oest de la provincia d'Ontario i les comarques gironines. Doctoral thesis. Girona, Universitat de Girona [Available at: <http://www.tdx.cat/handle/10803/70011>].

- (2013). "El nuevo paradigma agrosocial, futuro del nuevo campesinado emergente". Polis, 34 (12), 203-223 [Available at: <http://polis.revues.org/8831>].

Monllor, Neus; Guillamon, Jaume; Guirado, Carles; Medina, F. Xavier and Moreno, Ignacio (2014). "Cocina, transformaciones sociales y nuevos conceptos para nuevas prácticas alimentarias: El caso de la Cuina compromesa (Burg, Pirineo de Lleida)". Studium, Humanidades y Ciencias Sociales, 20, 213-256. 
Monllor, Neus; Roca, Anna and Ribas, Anna (2005). Proposta i aplicació d'un model de contracte territorial al Pla de l'Estany. Girona: Departament d'Agricultura, Ramaderia i Pesca i Càtedra de Pensament Territorial de la Universitat de Girona.

Niewolny, Kim and Lillard, Patrick (2010). "Expanding the boundaries of beginning farmer training and program development: a review of contemporary iniciatives to cultivate a new generation of American farmers". Journal of Agriculture, Food Systems and Community Development, 1, 65-88.

O'connor, Deirdre; Renting, Henk; Gorman, Monica and Kinsella, Jim (2006). "The Evolution of Rural Development in Europe and the Role of EU Policy". In: O’connor, Deirdre; Renting, Henk; Gorman, Monica and Kinsella, Jim (eds.). Driving Rural Development Policy and Practice in Seven EU Countries. Assen: Royal van Gorcum, 1-30.

OECD (Organization of Economic Cooperation and Development) (2006). New Rural Paradigm: policies and governance. Brussels: OCDE.

Padel, Susanne (2001). "Conversion to organic farming: a typical example of the diffusion of an innovation?”. Sociologia Ruralis, 41, 40-61.

Perez-Vitoria, Silvia (2010). El retorno de los campesinos. Una oportunidad para nuestra supervivencia. Barcelona: Icaria.

Petrini, Carlo (2005). Buono, polito e giusto. Principi di nuova gastronomia. Torino: Giulio Einaudi.

Pinto-Correia, Teresa; Gonzalez, Carla; Sutherland, Lee-Ann and Peneva, Mariya (2015). "Countryside consumption: transition towards lifestyle land management. In: Sutherland, Lee-Anna; Darnhofer, Ika; Zagata, Lukas and Wilson, Geoff (2015). Transition pathways towards sustainability in European agriculture. Wallingford: CABI, 69-84.

Ploeg, Jan Douwe van der (2006). "Agricultural production in crisis”. In: Cloke, Paul J.; Marsden, Terry and Mooney, Patrick (eds.). Handbook of Rural Studies. Londres: SAGE Publications, 258-277.

- (2008). The new peasantries: struggles for autonomy and sustainability in an era of empire and globalization. London: Routledge.

- (2010). "The food crisis, industrialized farming and the imperial regime". Journal of Agrarian Change, 10 (1), 98-106.

Ploeg, Jan Douwe van der and Marsden, Terry (eds.) (2008). Unfolding Webs. The dynamics of regional rural development. Assen: Royal van Gorcum.

Ploeg, Jan Douwe van der, Schneider, Sergio and Jinghong, Ye (2015). "Rural development: actors and practices". In: Milone, Pierluigi; Ventura, Flaminia and YE, Jingzhong (eds.) (2015). Constructing a new framework for rural development. Research in Rural Sociology and Development (Vol. 22). Bingley: Emerald Group Publishing Limited, 17-30.

Potter, Clive and Lobley, Matt (1996). "The farm family life cycle, succession paths and environmental change in Britains countryside". Journal of Agricultural Economics, 47, 172-190.

Riechmann, Jorge (2003). Cuidar la T(t)ierra. Politicas agrarias y alimentarias sostenibles para entrar en el siglo XXI. Barcelona: Icaria.

Rigby, Dan; Young, Trevol and Burton, Michael (2001). "The development of and prospects for organic farming in the UK". Food Policy, 26, 599-613.

Ruhf, Kathy; Immerman, Gaby, Toensmeier, Eric et al. (2003). "Who will farm". The Natural Farmer, 55 (2), Special Supplement on Beginning Farmers, 1-16. 
Sotтe, Franco (2003). "Young people, agriculture and entrepreneurship: key-points for a long-term strategy". The future of young farmers. Roma, 24-25 January 2003.

Sottomayor, Miguel, Tranter Richard and Costa Leonardo (2011). "Likelihood of succession and farmers' attitudes towards their future behaviour: evidence from a survey in Germany, the United Kingdom and Portugal". International Journal of Sociology of Agriculture and Food, 18 (2), 121-133.

Sutherland, Lee-Anna; Darnhofer, Ika; Zagata, Lukas and Wilson, Geoff (2015). Lifestyle farming: countryside consumption and transition towards new farming models in Transition pathways towards sustainability in European agriculture. Wallingford: CABI.

Ventura, Flaminia; Milone, Pierluigi and Ploeg, Jan Douwe van der (2010). "Understanding rural development dynamics". In: Milone, P. and Ventura, F. (eds.). Networking the rural. The future of green regions in Europe. Assen: Royal van Gorcum.

Viladomiu, Lourdes (2003). "Noves tendències de desenvolupament rural a Europa”. Quaderns Agraris, 28, 21-36.

Wilbur, Andrew (2014). "Cultivating Back-to-the-Landers: Networks of Knowledge in Rural Northern Italy”. Sociologia Ruralis, 54 (2), 167-185.

Williams, Fiona and Farrington, John (2006). "Succession and the future of farming: problem or perception?". The Rural citizen: governance, culture and wellbeing in the 21st century. Plymouth, 4-7 April 2006.

Woods, Michael (2005). Rural Geography: processes, responses and experiences in rural restructuring. London: SAGE Publications.

Zagata, Lukas and Lostak, Michal (2014). WP4 Final Report. Farming Transitions. Pathways towards regional sustainability of agriculture in Europe. [Available at: <http://www.farmpath.eu>]. 